\title{
Organisational sustainability - motivation in a semi-volunteer student organisation
}

\begin{abstract}
The motivation to study seems to decrease with age. Most students in higher education have only extrinsic motivation or do not have any motivation at all. At Budapest Business School there are four colleges of advanced studies, one at each faculty. Applicants must prove their motivation for extra-curricular activities and their ability for scientific thinking before entering these organisations. To keep quality standards high, it is important to have active members who are interested in the effective and smooth operation of the organisation. The main aim of this research was to reveal the various types of motivation present at Budapest Business School. The study is based on a questionnaire survey that includes statements from the Academic Motivation Scale. The survey also contains questions regarding students' social background, their motivations to join and their scientific activities. The study gives an insight into the structures, activities, the members' extrinsic and intrinsic motivational patterns and, on the other hand, how these organisations can be improved. It is investigated how scientific excellence can be sustained in a semi-volunteer student organisation.
\end{abstract}

Keywords: advanced studies, motivation, responsibility, student organisation

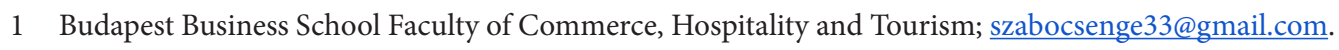

2 Budapest Business School Faculty of Commerce, Hospitality and Tourism; davidsuto1998@gmail.com. DOI: http://dx.doi.org/10.31570/Prosp 2019036. 


\section{Introduction}

As students at Budapest Business School and members of one of the colleges of advanced studies, we have always been interested in our fellow students' motivations at the university and in the organisation as well. We noticed a change of direction in the organisation which raises questions and is interesting for the community from a professional point of view. We were curious to know whether the same thing happened to the other colleges of advanced studies of the university and if the organisation can be sustained in this new form. That is why we started a research about the members' motivation to join and the factors that have been influencing their activity in the organisation.

We have formulated two hypotheses which could help us to answer the above questions. These were the following:

(1) Joining the college is primarily motivated by the prospect of expanding professional knowledge.

(2) Intrinsic motivations affect the activity of college members more than extrinsic ones.

\section{Motivations}

The topic of motivation appeared in philosophy, biology, psychology, education, economy and sociology in the second part of the 20th century. A generally accepted theory was not born but an agreement was reached in connection with the fact that "the question behind the concept of motivation is what moves and how the human act" (Reisz et al. 2008: 245).

\section{Motivation towards education}

Réthyné (2001) distinguishes two different levels of learning motivation: the intrinsic and the extrinsic motivation.

Intrinsic motivation refers to the inner tendency which expresses itself in the search for challenge or novelty, in the will to extend or practise one's skills, and discover or learn something new (Ryan and Deci 2000). There are researchers (e. g. Vallerand et al. 1992) who interpreted the intrinsic motivations with three types. They defined them 
as intrinsic motivation to know, to accomplish things, and to experience stimulation. Motivation to know "can be defined as the fact of performing an activity for the pleasure and the satisfaction that one experiences" (Vallerand et al. 1992: 1006), while acquiring new knowledge. We can talk about intrinsic motivation toward accomplishment, when "someone is engaged in an activity for the pleasure and satisfaction, experienced attempts to accomplish or create something" (ibid.). As to the third type, intrinsic motivation to experience stimulation, it occurs when someone is performing an activity in order to experience stimulating sensations.

Extrinsic motivation involves a variety of behavioural patterns, but unlike intrinsic ones, action here is motivated by reaching a goal external to the action itself. Vallerand and his colleagues (1992) distinguished three interdependent stages of external motivation. According to Kiss (2015), external regulation occurs when "behavior is controlled externally, as well as rewards and limitations. The second stage is introjected regulation which means the internalization of the former external equivalents." The third extrinsic stage in this case of identified regulation takes place when someone is studying because it is important for him, especially if it is not compulsory, but he could choose it for himself. This third stage is called regulation through identification.

\section{Motivations for applying to colleges of advanced studies}

Only those students apply to colleges of advanced studies who are dedicated, aspiring to professional development and invest time in expanding their knowledge. The motivation for applying to these colleges was previously researched by several experts. In the study of Szilágyi and Duráczky (2018), the primary motivation of applying to colleges of advanced studies was measured by pre-defined response options. Besides primary, other (non-primary) motivational factors also exist. Nearly two-thirds of the respondents chose the answer for application reasons "community and programmes", and more than half of them indicated that "building professional relationships and increasing professional knowledge" is the best option among the given answers. We believe that in order to provide a basis for sustainability, we need to take into consideration previous researches and different types of motivations, and we also need to expand the profile of colleges of advanced studies to meet students' needs in an often-changing environment. 


\section{Questionnaire survey methodology}

We created a questionnaire based on previous research studies in this field. The first block of the questionnaire consisted of questions about the students' personal data, social background and collected information about their studies. In the second block the questionnaire inquired about their scholarly performance and scientific achievements during their stay in the organisation. The next part measured the motivation of the application based on a former research in Hungary (Szilágyi-Duráczky 2018). Activity in the colleges was measured by 12 statements which were adapted from the Academic Motivation Scale (Tóth et al. 2018) originally constructed for a research (Vallerand et al. 1992) which studied motivations in higher education. The respondents rated on a scale from 1 to 7 how well different statements describe their activities in the organisation. We kept and adapted to colleges of advanced studies two statements per motivation type. To simplify the measurement of all factors, the overall score for each motivation type was calculated as an average of the answers given to the two statements belonging to each type. The average of the values of intrinsic and extrinsic motivation types gives the index values. At the end of the questionnaire we assessed the professional and scientific excellence of the members based on their participation in researches and competitions.

The questionnaire was sent on 26 February 2019 to each member of the organisation at all faculties. From the 88 active and passive members we received 70 valid answers. Survey response rates were as follows: Zalaegerszeg Faculty of Business Administration (ZFBA) - 15\%; Faculty of International Management and Business (FIMB) - 68\%; Faculty of Commerce, Hospitality and Tourism (FCHT) - 70\%; Faculty of Finance and Accountancy (FFA) - 87,5\%. As the surveys were anonymous, voluntary and selfadministered, we need to take self-selection bias into account when evaluating the results.

\section{Results}

\section{The respondents}

Information was collected about respondents' personal data, their social background, their studies and their potential leading position in an organisation. $30 \%$ of them had already assumed a leader position in one of the colleges of advanced studies. The sample is representative of the population of the colleges of advanced studies with respect to gender, age, and the type of training as well. 


\section{Motivations for joining}

Questions regarding the primary and further motives of the students for joining colleges of advanced studies were formulated on the pattern of the previously cited literature with predetermined answers. As shown in Table 1, increasing professional knowledge was mentioned as the primary motivation to apply. The importance of the programmes and belonging to a community was mentioned second most often. Participation in competitions, leveraging talent, and peer recommendation were also chosen by one-tenth of the members. Less than one-fifth of the respondents mentioned other answers.

Table 1. Main and other motivations for applying to a college of advanced studies (\%) $(N=70)$

\begin{tabular}{|l|c|c|}
\hline \multicolumn{1}{|c|}{ Motivations } & $\begin{array}{c}\text { Primary } \\
\text { motivation }\end{array}$ & $\begin{array}{c}\text { Other } \\
\text { motivations }\end{array}$ \\
\hline Increasing professional knowledge & 31.2 & 53.7 \\
\hline Community and programmes & 19.7 & 53.7 \\
\hline Participation in competitions & 10.4 & 40.3 \\
\hline Leveraging talent & 10.4 & 25.5 \\
\hline Student recommendation & 10.4 & $20, .9$ \\
\hline Building professional relationships & 7.5 & 52.2 \\
\hline Improving their chances in the labour market & 4.4 & 22.4 \\
\hline Teacher recommendation & 3.0 & 4.6 \\
\hline Scholarship opportunities & 1.5 & 29.9 \\
\hline Opportunity to study or work abroad & 1.5 & 13.2 \\
\hline Obtaining a leader position in professional life & 0 & 16.4 \\
\hline Improving university studying outcomes & 0 & 10.4 \\
\hline
\end{tabular}

As colleges of advanced studies are professional-scientific organisations, we expected that most of the students' motivation to join was the expansion of professional knowledge and professional relationships. The most important additional motivations turned out to be community and programmes as well as increasing professional knowledge. Building professional relationships and participation in competitions have a much greater role than in the case of primary motivations. Scholarship opportunities as motivational factors also played an important role. Improving the chances in the labour market, student recommendation and teacher recommendation were less often mentioned. 


\section{Intrinsic and extrinsic motivation in the members' activities}

The questionnaire included the twelve statements previously described which had to be graded on a Likert scale from 1 to 7 by the extent they were relevant to their own activities in the college of advanced studies.

Figure 1. The strength of intrinsic motivation types for all faculties

\section{Intrinsic motivation}

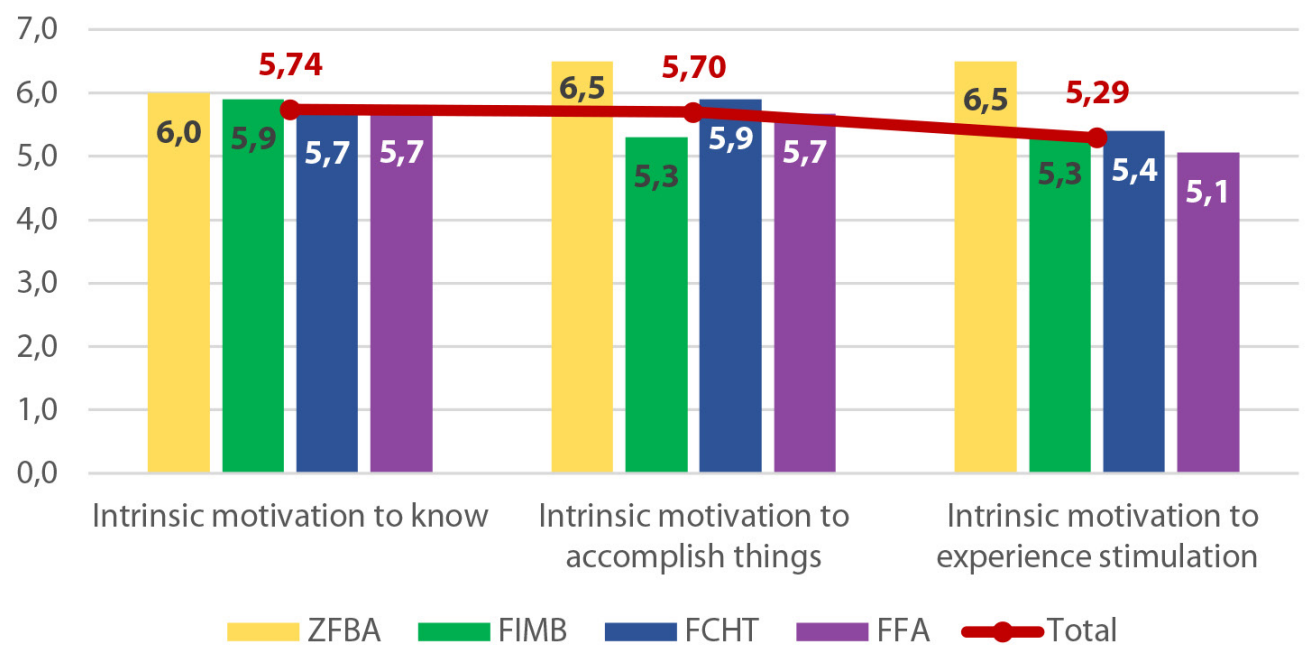

Source: own compilation

In the case of intrinsic motivations, the average score of statements reached 5.54 and the standard deviation amounted to 0.81 . Among the intrinsic motivations (Figure 1) motivation to know was best suited for the respondents, with an average of 5.74 points.

In the case of extrinsic motivations, the average score amounted to 4.47 and the standard deviation was 1.17. Among different types of extrinsic motivations (Figure 2), identified regulation received the highest score at all four faculties, which lags behind the average for any of the intrinsic motivation values. 
Figure 2. The strength of extrinsic motivation types at all four faculties

\section{Extrinsic motivation}

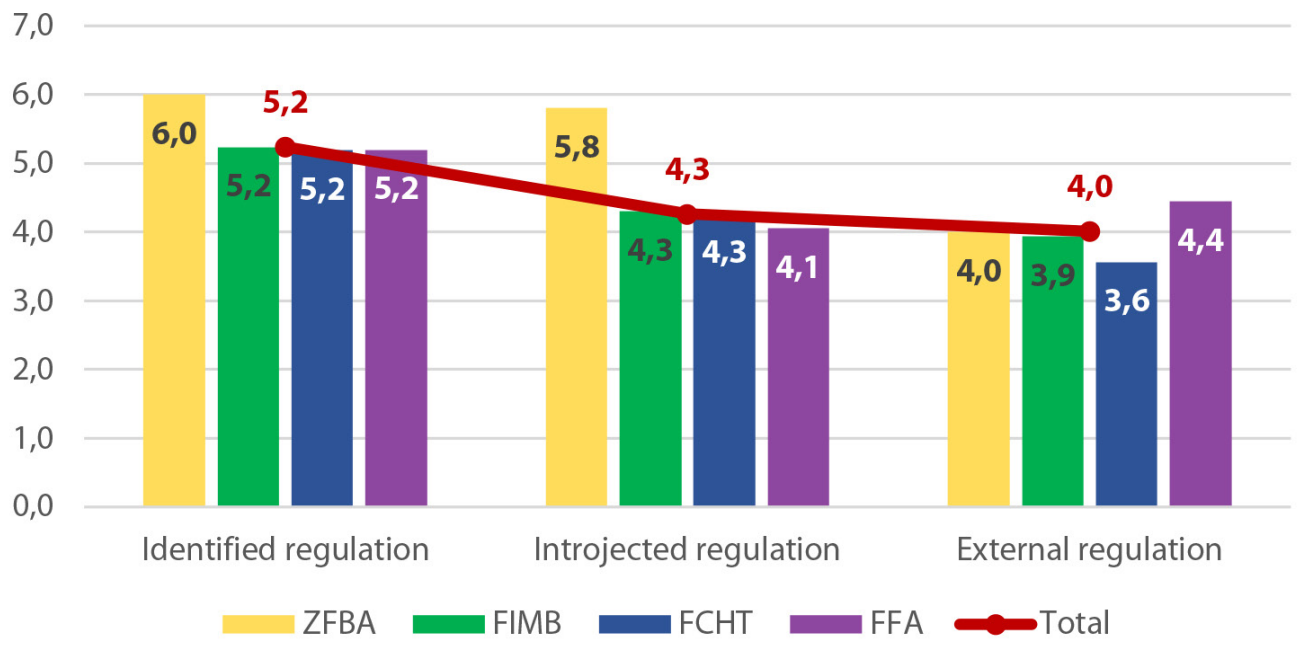

Source: own compilation

As a conclusion we can say that intrinsic and extrinsic motivations proved to be equally important for the members of the college of advanced studies, but the former ones were much more typical.

\section{Conclusion}

In conclusion it can be stated that the most typical motivations turned out to be the enrichment of professional knowledge, the community and programmes, and building professional relationships. These were followed by participation in competitions, with a very high percentage $(40.3 \%)$, which is probably due to the fact that many of the respondents have mistakenly considered the college of advanced studies as only an opportunity to take part in competitions. Scholarship opportunities were mentioned by one third of the respondents, which shows that it is important for the students to get a reward for their grades, or to be in a better position to apply for scholarships. Thus our first hypothesis has been confirmed by our results: the primary motivation of joining the college was the enrichment of professional knowledge.

The second hypothesis has also been confirmed, since we found that intrinsic motivation affects the activity of college members more than extrinsic ones. At all four 
faculties average scores of intrinsic motivations were higher than those of extrinsic ones. The greatest value, 5.74 points, is related to motivation to know as an intrinsic motivation, while external regulation as an extrinsic motivation factor has earned the lowest overall score in our survey. Thus second hypothesis has also been approved.

\section{References}

Kiss Á. G. (2015). Tanulási motivációk vizsgálata a Szent István Egyetem hallgatóinak körében [Studying motivation to know among students of Szent István University]. Studia Mundi - Economica, (2)3, 127-137. https://doi.org/10.18531/studia.mundi.2015.02.03.127-137.

Reisz T. - Kleisz T. - Kocsis M. (2008). Motiváció [Motivation]. In HEFOP 3.5.1 „Korszerü felnőttképzési módszerek kidolgozása és alkalmazása.” Andragógiai ismeretek. Budapest: Nemzeti Szakképzési és Felnőttképzési Intézet, 245-295.

Réthy E.-né (2001). Motivációs elképzelések [Motivational ideas]. In Golnhofer E. Nahalka I. (szerk.): A pedagógusok pedagógiája. Budapest: Nemzeti Tankönyvkiadó. Ryan, R. M. - Deci, E. L. (2000). Self-determination theory and the facilitation of intrinsic motivation, social development, and well-being. American Psychologist, (55)1, 68-78. https://doi.org/10.1037/0003-066x.55.1.68.

Szilágyi Á. - Duráczky B. (2018). Jelentkezési motivációk, hallgatói összetétel [Applying motivations, student compositions]. In Feledy B. (szerk.): Mit adtak nekünk a szakkollégiumok? I. A szakkollégisták motivációi, eredményei, hallgatói összetétele. Budapest: Társadalmi Reflexió Intézet.

Timár B. (szerk.) (2017). Elemzés. Diplomás pályakövetö rendszer müködése [Analysis. Graduate Career Tracking System]. Budapest: Állami Számvevőszék (State Audit Office).

Tóth-Király, I. - Orosz, G. - Dombi, E. - Jagodics, B. - Farkas, D. - Amoura, C. (2017). Cross-cultural comparative examination of the Academic Motivation Scale using exploratory structural equation modelling. Personality and Individual Differences, 106, 130-135. https://doi.org/10.1016/j.paid.2016.10.048.

Vallerand, R. J. - Pelletier, L. G. - Blais, M. R. - Brière, N. M. - Senécal, C. - Valliéres, E. F. (1992). The Academic Motivation Scale: A measure of intrinsic, extrinsic, and amotivation in education. Educational and Psychological Measurement, (52)4, 10031017. https://doi.org/10.1177/0013164492052004025. 